\title{
EUROCAL - The European cooperation of accredited calibration labs
}

\author{
R. Honig ${ }^{1}$, P. Ulbig ${ }^{2}$ and F. Drozda ${ }^{3}$ \\ ${ }_{1}$ Amtest-TM s.r.o. / MI-Europe, s.r.o (Vice-Chair of ČKS and KZSR), Svatováclavská 408, Uherské Hradiště, 686 01, Czech Republic \\ ${ }^{2}$ Physikalisch-Technische Bundesanstalt (PTB) (Chair of the DKD), Bundesallee 100, D-38116 Braunschweig, Germany \\ ${ }^{3}$ AMANS s.r.o. (Chair of the KZSR), Šulekova 33, 81103 Bratislava, Slovakia
}

\begin{abstract}
Although the realization of units and maintaining national metrology standards is the responsibility of National Metrology Institutes (NMI), the ultimate task of dissemination of traceability towards industry is usually carried out by number of accredited and non-accredited calibration labs. In many countries these calibration labs form associations to establish a good cooperation between them, to exchange information and to support the calibration sector. European Calibration Association (EUROCAL) aims to become a forum for the coordination and harmonization of cooperation among associations of calibration laboratories. EUROCAL is professional interest group with main focus on exchange of information and knowledge between national associations in the field of calibration. The objectives of EUROCAL are to improve, strengthen and harmonize the European sector of calibration laboratories. In addition EUROCAL aims at coordinating the creation, improvement, unification, maintenance and international acceptance of calibration guides or other technical documents, assuring their correctness and quality level, based on knowledge and experience of calibration laboratories and their experts. As EUROCAL represents a large number of accredited calibration labs via the national associations, EUROCAL develops common positions regarding accreditation with the aim to present opinion and coordinated interests of European calibration lab associations to other European or also international institutions.
\end{abstract}

\begin{abstract}
Résumé. Bien que la réalisation des unités et le suivi des normes de métrologie nationales est de la responsabilité de NMI, la tâche ultime de la diffusion de la traçabilité vers l'industrie est habituellement effectuée par les laboratoires d'étalonnage accrédités et non accrédités. Dans de nombreux pays, ces laboratoires d'étalonnage forment des associations pour établir une bonne coopération entre eux, d'échanger des informations et à soutenir le secteur de l'étalonnage. Association européenne d'étalonnage (de EUROCAL) vise à devenir un forum pour la coordination et l'harmonisation de la coopération entre les associations de laboratoires d'étalonnage. EUROCAL est groupe d'intérêt professionnel en mettant l'accent principal sur l'échange d'informations et de connaissances entre les associations nationales dans le domaine de l'étalonnage. Les objectifs d' EUROCAL sont d'améliorer, de renforcer et d'harmoniser le secteur européen des laboratoires d'étalonnage. En outre EUROCAL vise à coordonner la création, l'amélioration, l'unification, la maintenance et l'acceptation internationale des guides de calibrage ou d'autres documents techniques, en assurant leur exactitude et la qualité niveau, basée sur la connaissance et l'expérience des laboratoires d'étalonnage et de leurs experts. Comme EUROCAL représente un grand nombre de laboratoires d'étalonnage accrédités par les associations nationales, EUROCAL développe des positions communes concernant l'accréditation dans le but de présenter l'opinion et les intérêts coordonnés des associations européennes d'étalonnage de laboratoire à d'autres institutions internationales ou européennes aussi.
\end{abstract}

\section{Background of EUROCAL idea}

It is probably part of the human nature to tend to create various groups aimed on different tasks and the metrology seems to fit to this scheme, too. Therefore it is no surprise that in some countries calibration labs form associations to establish a good cooperation between them, to exchange information and to support the calibration sector. Establishing of the association of calibration laboratories at some of the East-European countries have been inspired at early 90's of last century by the WEEC activities on the west side. When the EAL was founded on the base of the WECC and WELAC in

${ }^{1}$ romanhonig@mintl.com ${ }^{2}$ Peter.Ulbig@ptb.de ${ }^{3}$ drozdaf@amans.sk the 1994, the EAL took up only a part of the activities of the WECC, which were close to the accreditation activity and a just few other activities, which did not presented the conflict of interests with accreditation activity in the European accreditation. The remaining activities of the former WECC, that have not been took up by EAL, were left unattended. This is where the motive of constituting the local National association of calibration laboratories originated and later, based on additional international activities also wider international association idea came to play. Using the knowledge and information obtained during the meetings of the $4 \mathrm{E}-\mathrm{CZ}$ association 
(www.4e.cz), which represents direct relation to European cooperation among EA, EUROLAB, EURACHEM and EURAMET, had lead to the conclusion that for achieving the full closed structure covering most of the subjects of the metrology area, including the calibration labs from industrial sphere, there is missing another part that can be named European Calibration Association (furthermore called EUROCAL), which would extend the existing activities of $4 \mathrm{E}$ to actual $5 \mathrm{E}$.

\subsection{Why another international association?}

Compared with other types of laboratories like testing labs calibration labs have a more specific task and therefore there number is lower. For this reason it seemed to be important having e.g. possibility to present competent interests of the calibration laboratories towards the accreditation authority EA at coordinated way with aim to unify approaches of National accreditation bodies and achieve comparable level of demands, but also comparable level of possibilities of accredited care for measurements and calibration of equipments at each state of Europe. Such approaches unification is mainly the question of communication, as the experience shows that the "good things are contagious", i.e. will spread partially on their own. Also the international chance for exchange of information and opinions would very likely lead to the improvements at the area of care for measurements and metrology at context of international companies cooperation. Another reason behind EUROCAL idea was the fact that at many cases the same task is repeated at the National level when preparing master calibration procedures, so the international cooperation on creating these procedures would result at saving a lot of time and effort that can be spent better way.

\subsection{Pre-agreement acts}

Following the original EUROCAL idea presented at the RMO 2008 [1], there were several ad-hoc meetings made during various events and occasions (CFM congress 2009, NCSLi 2009, CPEM 2010, NCSLi 2010, NCSLi 2011, CFM congress 2011), where the goal was discussed with people from different organizations at Europe namely large calibration labs, but also representatives of local metrology associations and international organizations like EUROLAB, EURAMET and NCSLi.

General reception of the EUROCAL idea was practically at all cases very positive; everyone was interested to learn more and had seen possible positive impact of such association in case it comes into life, but nobody would volunteer to get themselves personally involved at managing the real start of EUROCAL. This changed at early 2012, after unsuccessful trial to find the way to fit the EUROCAL into structure of the TC's within the EURAMET. The decision was then made to form the EUROCAL as an independent entity and let it grow to its task. Text of the EUROCAL agreement was discussed and put together during first half of the 2012 and everything was being prepared for official signing this agreement by the parties during the autumn conference of Czech Calibration association at Lisek, where representatives of DKD and KZSR were invited for this reason.

\section{Starting the EUROCAL}

\subsection{EUROCAL agreement signed}

In a first step this has been agreed and established between the Czech, German and Slovakian associations of calibration labs (ČKS, DKD and KZSR) in October 2012 [2],[3]. Original EUROCAL agreement was signed by chairmen of these associations, Mr. J. Kazda (ČCKS), Mr. P. Ulbig (DKD) and Mr. F. Drozda (KZSR).

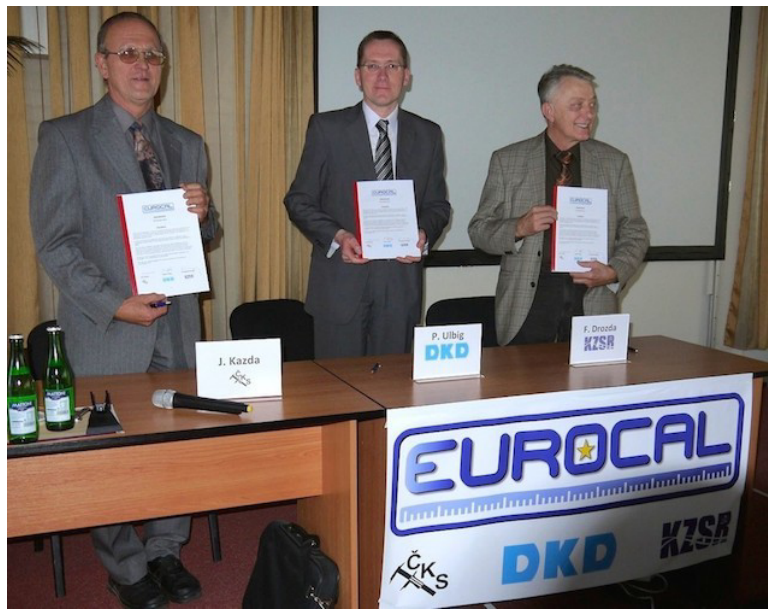

In a second step the Metrology Group of the Serbian Chamber of Commerce and Industry joined EUROCAL in March 2015. Now EUROCAL is representing more than 500 accredited European calibration labs with increasing tendency.

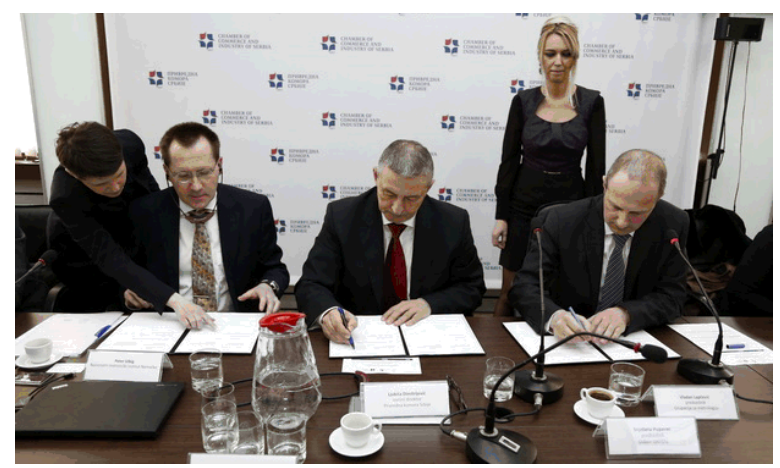

\subsection{Focus of EUROCAL activities}

Although the realization of units and maintaining national metrology standards is the responsibility of national metrology institutes, the ultimate task of dissemination of traceability towards industry is usually carried out by number of accredited and non-accredited calibration labs. The EUROCAL aims to become a forum for the coordination and harmonization of cooperation among associations of calibration laboratories, primarily, but not 
exclusively, from EU countries. EUROCAL represents a professional interest group with main focus on exchange of information and knowledge between national associations in the field of calibration.

EUROCAL aims to cooperate with the so-called 4E European institutions i. e. EURAMET, EA, EUROLAB and EURACHEM.

The objectives of EUROCAL are to improve, strengthen and harmonize the European sector of calibration laboratories. These objectives shall be reached by supporting the information exchange between members about developments in the field of calibration. In addition EUROCAL aims at coordinating the creation, improvement, unification, maintenance and international acceptance of calibration guides or other technical documents with the aim of assuring their correctness and required quality level, based on knowledge and experience of calibration laboratories and their experts within Europe. As EUROCAL represents a large number of accredited calibration labs via the national associations EUROCAL intends to develop common positions regarding accreditation with the aim to present opinion and coordinated interests of European calibration lab associations to other European or also international institutions. An important goal of the work of EUROCAL is to support interlaboratory comparisons/proficiency tests, as the accredited calibration laboratories have to develop proficiency test programs as one of the essential tools to demonstrate competence.

\section{Future ideas}

\subsection{Proposal for EUROCAL growth}

EUROCAL desire is to become the European coverage of the national, or if it turns to be suitable also regional Calibration Associations, where the members will be the existing or maybe only at the future (inspired by this article) established national Associations of calibration laboratories, focusing their activities to the problematic of calibration of equipments, measurements and care for measurements at company perspective. Each member would delegate his representative and also establish group of the TC's covering the area of specializations that are interesting for particular member. The active regular or irregular (ad-hoc) meetings of representatives for particular specializations would follow, which could form coordinated opinions on particular subjects and EUROCAL would aim to present them towards the EA, TC - ISO or EN, or other authorities and organizations on behalf of members, backed up by their experiences and qualified requirements. As the metrology is mainly technical branch, in principle international and apolitical, it is possible to assume that the consensus can be achieved easier and the subjects affecting the industrial metrology can be directed towards right and better direction. Future EUROCAL meetings may be called together with large international conferences like CPEM, TEMPMEKO, CIM and similar.

\subsection{Main areas of EUROCAL current and future activities}

EUROCAL is currently preparing for making survey of national calibration guides and needs for European harmonised guides, prepared at cooperation of the respective TC's of each member. The list of existing procedures is being sorted per significance and priorities will be set around the most frequently used existing procedures. This task will continue with definition of rules and transparent procedures for the creation of new calibration guides as well as for the improvement of existing ones. Another task for EUROCAL is preparing the survey of needs of calibration labs, e. g. in the field of measurement uncertainty, aimed to provide opinions and comments for the ongoing preparation of the GUM update. Same goal is also oriented on preparation of the opinions for the prepared update of the ISO 17025, including ideas concerning demands for unification of Criteria standards for Accreditation of laboratories and Certification of quality management systems and also activities concerning unification of accreditation criteria, expertise level and approaches of assessors as well as the education activities leading to such unification at the area of calibration labs accreditation. Further topics would include consideration of potential variants of procedures for calibration in the laboratory, as well as in case of calibration on customer's site, i. e. out of the calibration laboratory. Finally there is ongoing support for interlaboratory comparisons of calibration labs as the most effective way of proving their competence and the appropriate set level of their CMC's.

\section{Joining the EUROCAL}

\subsection{Accession form to EUROCAL}

EUROCAL accession requires filling the accession form, which is a simple document expressing willingness of applying member to participate on the EUROCAL activities. Full text of accession form is available for download from EUROCAL web (www.eurocal.eu)

\subsection{Establishing National association of calibration laboratories}

Although there is the individual membership available at EUROCAL, it is definitively preferred to have some kind of collective members representing the national or regional calibration laboratories. If there is none such association existing yet at your area, you can try to originate it. To achieve this goal easier, EUROCAL is working on creating rough draft of the document with proposed structure of the national association of calibration labs. This can be used as a frame for constituting such association, after adopting it to the requirements of the local legal rules applicable for such kind of associations at particular country. 
Web of Conferences

\section{References}

1. F. Drozda, R. Honig, $I^{\text {st }}$ RMO 2008; $20^{\text {th }} I M S$

(Dubrovnik, Croatia, 2008)

2. P. Ulbig, R. Honig, $45^{\text {th }}$ Conference $\check{C} K S$ (Lísek,

Czech Republic, 2012)

3. J. Horský, Metrologie (CZ) 4, 23 (2012) 